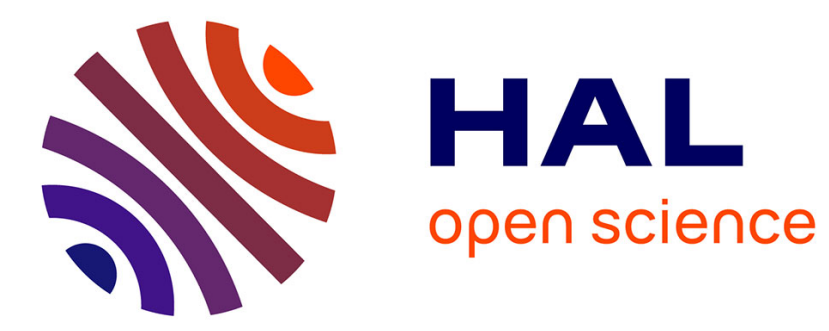

\title{
Photochemistry and photoinhibition of the H-cluster of FeFe hydrogenases
}

Matteo Sensi, Carole Baffert, Vincent Fourmond, Luca de Gioia, Luca Bertini, Christophe Léger

\section{> To cite this version:}

Matteo Sensi, Carole Baffert, Vincent Fourmond, Luca de Gioia, Luca Bertini, et al.. Photochemistry and photoinhibition of the H-cluster of FeFe hydrogenases. Sustainable Energy \& Fuels, 2021, 5 (17), pp.4248-4260. 10.1039/D1SE00756D . hal-03358063

\section{HAL Id: hal-03358063 https://hal.science/hal-03358063}

Submitted on 29 Sep 2021

HAL is a multi-disciplinary open access archive for the deposit and dissemination of scientific research documents, whether they are published or not. The documents may come from teaching and research institutions in France or abroad, or from public or private research centers.
L'archive ouverte pluridisciplinaire HAL, est destinée au dépôt et à la diffusion de documents scientifiques de niveau recherche, publiés ou non, émanant des établissements d'enseignement et de recherche français ou étrangers, des laboratoires publics ou privés. 


\section{Photochemistry and photoinhibition of the H-cluster of FeFe hydrogenases}

Matteo Sensi $i^{1,2,3}$, Carole Baffert ${ }^{2}$, Vincent Fourmond ${ }^{2}$, Luca de Gioia ${ }^{3}$, Luca Bertini ${ }^{3}$, Christophe Léger ${ }^{2}$.

1. Department of Life Sciences, University of Modena and Reggio Emilia, Modena, Italy

2. Laboratoire de Bioénergétique et Ingénierie des Protéines, CNRS, Aix Marseille Université, Institut de Microbiologie de la Méditerranée, Institut Microbiologie, Bioénergies et Biotechnologie, Marseille, France

3. Department of Biotechnology and Biosciences, University of Milano-Bicocca, Milan, Italy

\section{Abstract}

Hydrogenases are enzymes that catalyze the oxidation and production of molecular hydrogen. For about fifteen years, there have been many reports about the successful connection of these enzymes to photosensitizers with the aim of designing $\mathrm{H}_{2}$ photoproduction systems, but relatively little attention has been paid to whether and why illumination may affect the catalytic properties of the enzyme. In all hydrogenases, hydrogen activation occurs at an inorganic active site that includes at least one Fe-carbonyl motif, which may make it sensitive to irradiation. Here we review the evidence that hydrogenases are indeed photosensitive. We focus mainly on the so-called FeFe hydrogenases; their active site, called the $\mathrm{H}$-cluster, consists of a [4Fe4S] cluster that is bound by a cysteine sulfur to a diiron site. The iron atoms of the binuclear cluster are coordinated by carbonyl and cyanide ligands and an azadithiolate group. We describe the effects of UV-visible light irradiation on the enzyme under cryogenic or turnover conditions and the photoreactivity of model complexes that mimic the diiron site. We emphasize the dependence of the photochemical processes on wavelength, and warn about $\mathrm{FeFe}$ hydrogenase photoinhibition, which should probably be considered when attempts are made to use FeFe hydrogenases for the artificial photosynthesis of solar fuels. We also underline the relevance of studies of synthetic mimics of the H-cluster for understanding at atomistic level the photochemical processes observed in the enzyme.

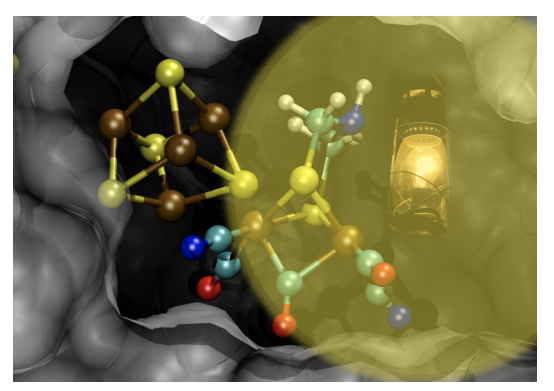

TOC summary: the photosensitivity of the active site of hydrogenases is an opportunity for studying its reactivity. However, the photoinhibition of certain hydrogenases may have a negative impact on $\mathrm{H}_{2}$ photoproduction. 


\section{Introduction}

Dihydrogen is a very common energy vector in Nature, as most microorganisms either oxidize or produce $\mathrm{H}_{2}$ in relation to their energy metabolism. These reactions are catalyzed by enzymes called hydrogenase ${ }^{1}$ and nitrogenases.

$\mathrm{H}_{2}$ oxidation occurs in relation to bacterial respiration: it is coupled to the reduction of a number of electron acceptors such as sulfate in sulfate reducing bacteria or $\mathrm{O}_{2}$ in Knallgas bacteria, and the free energy of the reaction is used for producing chemical energy in the form of ATP.

The dihydrogen that is consumed by this process can be produced in a number of ways, either in the same microorganism or in a microorganism from the same consortium.

The most prominent $\mathrm{H}_{2}$-producing metabolic pathway is dark-fermentation ${ }^{2}$, as e.g. occurs in strictly anaerobic Clostridial species ${ }^{3}$ or in enteric bacteria such as Escherichia coli ${ }^{2}$.

$\mathrm{H}_{2}$ is also a byproduct of the reduction of $\mathrm{N}_{2}$ to $\mathrm{NH}_{3}$, a key step in the global nitrogen cycle which occurs e.g. in cyanobacteria: the latter reaction is catalyzed by the enzyme nitrogenase, which evolves at least one molecule of $\mathrm{H}_{2}$ per $\mathrm{N}_{2}$ reduced ${ }^{4,5}$.

Biological splitting of water into $\mathrm{O}_{2}$ and $\mathrm{H}_{2}$ can also be observed in photosynthetic microorganisms such as green algae and cyanobacteria ${ }^{6}$, but the combination of $\mathrm{O}_{2}$ evolution and $\mathrm{H}_{2}$ production is not a natural physiological pathway ${ }^{7}$, and it is severely limited by the oxygen sensitivity of the enzymes involved in $\mathrm{H}_{2}$ production: hydrogenase or nitrogenase ${ }^{6,8-11}$. Efforts have been made to genetically engineer the enzymes ${ }^{12-14}$ or the strains $^{10}$ of these photosynthetic microorganisms, aiming for continuous, light-driven biological $\mathrm{H}_{2}$ production ${ }^{9-15}$. Another strategy to work around the $\mathrm{O}_{2}$ sensitivity problem in microalgae consists in alternating aerobic and $\mathrm{H}_{2}$ production phases by regulating the activity of Photosystem II; reducing equivalents are stored in the form of starch during the aerobic phase and then fed into hydrogenase via Photosystem I ${ }^{11,16}$. Alternatively, spatial separation of water oxidation and $\mathrm{H}_{2}$ production can also prevent nitrogenase inhibition by $\mathrm{O}_{2}$ in cyanobacteria ${ }^{11}$.

Biological, photosynthetic $\mathrm{H}_{2}$-production is therefore not easily achieved ${ }^{17}$, but chemists have long worked towards the goal of water-splitting-based hydrogen production by designing original semi-artificial systems that interface hydrogenases or hydrogenase mimics with either photoactive materials or molecular photosensitizers, including the photosystems involved in natural photosynthesis ${ }^{18-26}$.

Regarding the hybrid devices that include a photosynthetic enzyme, limitations may arise from the photodamage of the photosystems, which has been thoroughly studied by the photosynthesis community ${ }^{27-30}$. In vivo, the effect of the photodamage is balanced by de novo synthesis and repair mechanisms, but in vitro the damage decreases the stability of the hybrid systems ${ }^{31,32}$.

An Achilles' heel of the artificial photoproduction systems that has received much less attention is the electron acceptor side: there is published evidence that some hydrogenases are sensitive to light irradiation, but this was rarely considered as a potential weakness ${ }^{25,33,34}$. 
Nature makes three distinct enzymes to heterolytically split molecular $\mathrm{H}_{2}$. The so-called "NiFe hydrogenases" and "FeFe hydrogenases" both catalyze $\mathrm{H}_{2}$ oxidation and production at a binuclear metal center and have been considered in relation to the design of artificial photosynthesis systems. In contrast, "Fe hydrogenases" catalyze hydride transfer from $\mathrm{H}_{2}$ to methenyl-tetrahydromethanopterin, an organic substrate involved in microbial methane production. All three types of active sites contain at least one Fe-carbonyl bond ${ }^{33}$, and are sensitive to light but in a different manner, and according to mechanisms that have not been fully identified.

The active site of Fe hydrogenases ${ }^{34}$ is inactivated by exposure to UV-A (320-400 nm) or blue-light $(400-500 \mathrm{~nm})$, as a result of $\mathrm{Fe}$ release from the cofactor ${ }^{35}$. The enzyme is protected from light-induced inactivation by the binding of the inhibitor $\mathrm{CO}^{35}$ and, in the particular case of the enzyme from Methanothermobacter marburgensis, by its oligomerization $^{35}$. A key aspartate residue and some protein rearrangements are involved in the Fe hydrogenase protection from light-induced decomposition of the active site ${ }^{36}$.

The active site of NiFe hydrogenases exists in the dark in a number of forms, some of which (the so-called $\mathrm{Ni}_{\mathrm{u}}-\mathrm{A}, \mathrm{Ni}_{\mathrm{r}}-\mathrm{B}, \mathrm{Ni}-\mathrm{C}$ and $\mathrm{Ni}_{\mathrm{a}}-\mathrm{L}$ states) are EPR active. $\mathrm{Ni}_{\mathrm{u}}-\mathrm{A}$ and $\mathrm{Ni}_{\mathrm{r}}-\mathrm{B}$ correspond to oxidized, inactive states of the enzyme that disappear upon reductive activation of the enzyme. The $\mathrm{Ni}_{\mathrm{u}}-\mathrm{A}^{37}$ and $\mathrm{Ni}_{\mathrm{a}}-\mathrm{C}^{38-41}$ states and the EPR-silent $\mathrm{Ni}_{\mathrm{a}}-\mathrm{S}^{42,43}$ and $\mathrm{Ni}-\mathrm{S}-\mathrm{CO}^{44-47}$ states are all altered upon irradiation with visible light under cryogenic conditions. $\mathrm{Ni}_{\mathrm{a}} \mathrm{C}$ is an intermediate in the catalytic cycle, which bears a bridging hydride. $\mathrm{Ni}_{\mathrm{a}}-\mathrm{C}$ is photoconverted under cryogenic temperatures into $\mathrm{Ni}_{\mathrm{a}}-\mathrm{L}$, where the electrons are formally stored on the nickel ion. Additionally, this photoconversion results in the change of the protonation state of a terminal $\mathrm{Ni}$-coordinated Cys residue ${ }^{48}$. The photoproduct $\mathrm{Ni}_{\mathrm{a}}-\mathrm{L}$ can also be formed in the dark at ambient temperature ${ }^{49}$. The $\mathrm{CO}$-inhibited $\mathrm{Ni}_{\mathrm{a}}-\mathrm{S}$ state is light-sensitive: the extrinsic Ni-bound $\mathrm{CO}$ dissociates under illumination at cryogenic temperature $(<120 \mathrm{~K})$ restoring the catalytically relevant $\mathrm{Ni}_{\mathrm{a}}-\mathrm{S}$ intermediate ${ }^{44-47}$. Illumination with blue light accelerates the reactivation of the $\mathrm{Ni}_{\mathrm{r}}-\mathrm{B}$ state of the enzyme from Aquifex aeolicus at room temperature ${ }^{50}$. A mechanism for the removal of the bridging $\mathrm{OH}$ ligand from the $\mathrm{N}_{\mathrm{i}} \mathrm{r}-\mathrm{S}$ inactive ready state upon irradiation has been suggested ${ }^{51}$. Re-activation can also be triggered by light under cryogenic conditions in the protein crystals ${ }^{52}$. We are not aware of any evidence that $\mathrm{NiFe}$ hydrogenases are damaged upon irradiation.

In the context of designing $\mathrm{H}_{2}$ photoproduction devices, FeFe hydrogenase and their synthetic mimics are preferred because they are deemed more active for $\mathrm{H}_{2}$ production ${ }^{53,54}$. In this review we focus on FeFe hydrogenases and their biomimetic models, and we discuss the various effects that have been observed upon irradiation.

\section{The structure of FeFe hydrogenases}

The photochemical properties of FeFe hydrogenases are determined by the electronic structure of their inorganic cofactors. The active site of FeFe hydrogenases ${ }^{55}$, called the $\mathrm{H}$-cluster, consists of two subclusters bridged and attached to the protein matrix by a cysteine residue: a canonical $[4 \mathrm{Fe} 4 \mathrm{~S}]_{\mathrm{H}}$ cluster and a $[2 \mathrm{Fe}]_{\mathrm{H}}$ site; the two Fe ions are called proximal, $\mathrm{Fe}_{\mathrm{P}}$, and distal, $\mathrm{Fe}_{\mathrm{D}}$, in reference to the distance to the $[4 \mathrm{Fe} 4 \mathrm{~S}]_{\mathrm{H}}$ subcluster. Each 
iron in the $[2 \mathrm{Fe}]_{\mathrm{H}}$ site binds a $\mathrm{CO}$ and a $\mathrm{CN}^{-}$ligand and the two $\mathrm{Fe}$ are bridged by a further $\mathrm{CO}$ and an azadithiolate (adt) group (figure 1).

Although many states of the $\mathrm{H}$-cluster have been observed using EPR and FTIR spectroscopy ${ }^{55-66}$, most investigations of the photochemistry of FeFe hydrogenases have focused on the so-called $\mathrm{H}_{\mathrm{ox}}, \mathrm{H}_{\mathrm{ox}}-\mathrm{CO}$ and $\mathrm{H}_{\text {inact }}$ states. In the $\mathrm{H}_{\mathrm{ox}}-\mathrm{CO}$ and $\mathrm{H}_{\text {inact }}$ states, extrinsic $\mathrm{CO}$ or $\mathrm{HS}^{-}$ligands, respectively, coordinate the $\mathrm{Fe}_{\mathrm{D}}$ apical site ${ }^{67,68}$ (Figure 1). Both $\mathrm{CO}$ and sulfide binding prevent the damage of the enzyme by $\mathrm{O}_{2}{ }^{69-71}$, showing that they target the same binding site as $\mathrm{O}_{2}{ }^{68,72}$. One-electron reduction of $\mathrm{H}_{\mathrm{ox}}$ results in the accumulation of two redox species $\left(\mathrm{H}_{\text {red }}\right.$ and $\left.\mathrm{H}_{\text {red }} \mathrm{H}^{+}\right)$related by proton coupled electron redistribution ${ }^{73}$. More reduced states, characterized by the presence of a terminal hydride ligand on $\mathrm{Fe}_{\mathrm{D}}$, are observed under certain conditions, in particular when proton transfer is blocked ${ }^{64,74-76}$. The enzyme photochemistry under reducing conditions was also investigated using electrochemistry.

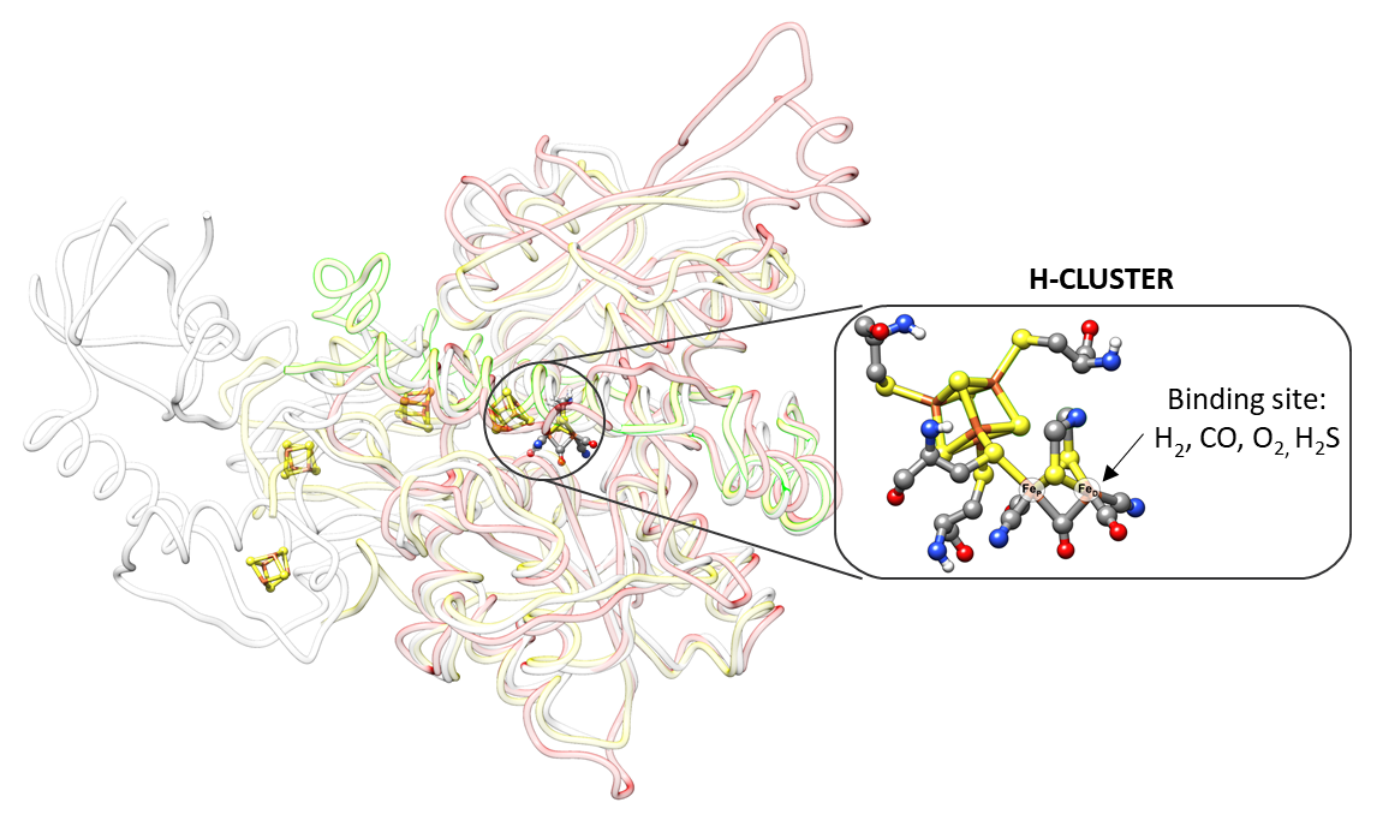

Figure 1 - Structure of the FeFe hydrogenase from C. pasteurianum Cpl (white, PDB code: 6N59), C. reinhardtii HydA1 (red, PDB code: $3 L X 4$ ) and D. vulgaris str. Hildenborough DdHydAB (yellow, PDB code: 1HFE). The FeS clusters and the H-cluster are shown in ball and stick representation.

Investigations on the photochemical properties of the $\mathrm{H}$-cluster aimed at understanding the effect of light irradiation and the nature and reactivity of the photoproducts. Fast or ultrafast processes are difficult to observe, but the dynamics of the excited states can be studied using quantum chemistry with time-dependent DFT (TDDFT).

In general, electronic excited states are always calculated from the ground state wave-function, whose characterization is required before the effect of excitation can be investigated. The ground state electronic structure of the $\mathrm{H}$-cluster in the $\mathrm{H}_{\mathrm{ox}}$ and $\mathrm{H}_{\mathrm{ox}}-\mathrm{CO}$ states can be described as a three-spin system: the $[2 \mathrm{Fe}]_{H}$ site has a spin of $1 / 2$, each [2Fe2S] layer of the $[4 \mathrm{Fe} 4 \mathrm{~S}]_{\mathrm{H}}$ cluster has $S=S(2)+S(5 / 2)=9 / 2$ (figure 2). The iron atoms of the binuclear subcluster, in both $\mathrm{H}_{\mathrm{ox}}$ and $\mathrm{H}_{\mathrm{ox}}-\mathrm{CO}$ states of the $\mathrm{H}$-cluster, are in the Fe'Fe" redox configuration. The attribution of the redox state to $\mathrm{Fe}_{\mathrm{P}}$ and $\mathrm{Fe}_{\mathrm{D}}$ is not trivial: $\mathrm{FTIR} \mathrm{R}^{66,67}$, 
$\mathrm{EPR}^{77}$ and $\mathrm{DFT}^{78}$ studies suggest that $\mathrm{Fe}_{\mathrm{D}}$ is the $\mathrm{Fe}^{\mathrm{l}}$ while ENDOR, $\mathrm{HYSCORE}^{79}$ and FTIR spectroelectrochemistry ${ }^{61,65,80}$ data support the paramagnetic $\mathrm{Fe}^{\prime}$ nature of $\mathrm{Fe}_{\mathrm{p}}$. The $[4 \mathrm{Fe} 4 \mathrm{~S}]_{\mathrm{H}}{ }^{2+}$ cluster consists of two [2Fe2S] layers coupled antiferromagnetically, each formed by one $\mathrm{Fe}^{\mathrm{II}}$ and one $\mathrm{Fe}^{\mathrm{II}}$ high-spin ions, coupled ferromagnetically, giving an overall low-spin state $^{58,78,81,82}$.

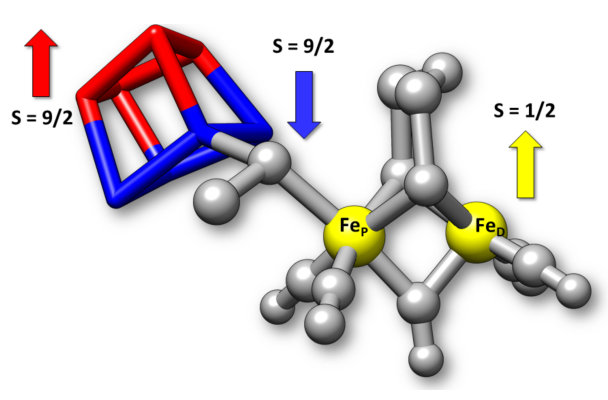

Figure 2 - Three-spin model of the H-cluster in the $H_{o x}$ state.

The frontier molecular orbitals (FMOs) of the H-cluster in the ground state (GS) obtained from DFT calculation are localized on the $[4 \mathrm{Fe} 4 \mathrm{~S}]_{\mathrm{H}}$ cluster and/or the $[2 \mathrm{Fe}]_{\mathrm{H}}$ site, depending on the state of the $\mathrm{H}$-cluster ${ }^{81,83}$ We have calculated the frontier molecular orbitals (FMOs) of $\mathrm{H}_{\mathrm{ox}}-\mathrm{CO}$ in the ground state ${ }^{84}$. In this case, single occupied HOMO and LUMO are localized on the $[4 \mathrm{Fe} 4 \mathrm{~S}]_{\mathrm{H}}$ and on the $[2 \mathrm{Fe}]_{\mathrm{H}}$ respectively. We described the $\mathrm{H}$-cluster as a dyad system that consists of two fragments covalently bound to one another: the [4Fe4S $]_{H}$ cluster and the $[2 \mathrm{Fe}]_{\mathrm{H}}$ site. As shown in scheme 1, the excited states decay of this system can be described in terms of a charge-transfer (CT) or a localized mono-electronic transition depending on the orbital composition of the FMOs involved ${ }^{85,86}$.

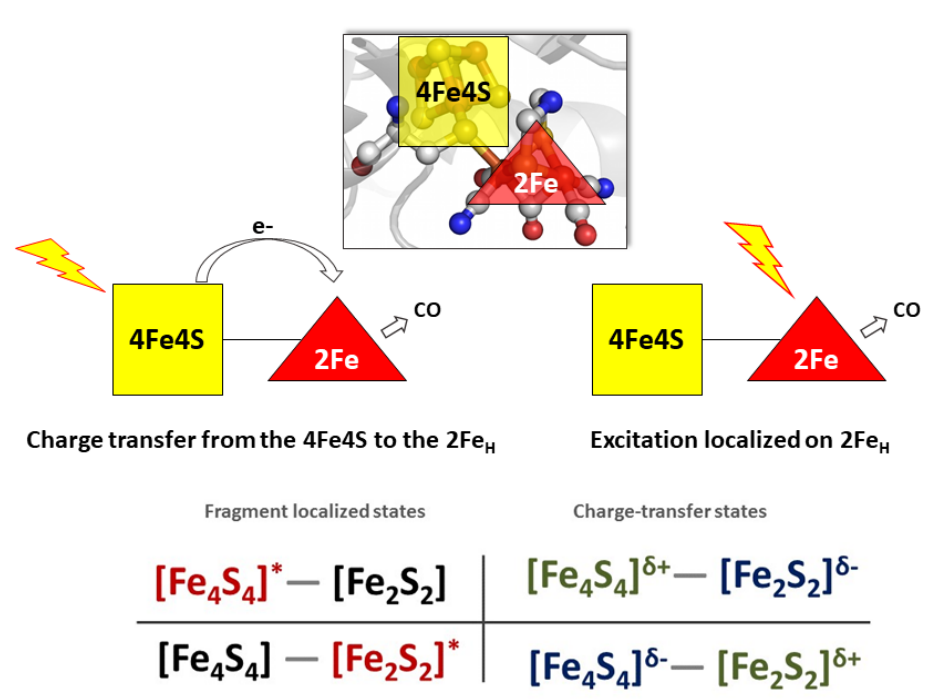

Scheme 1 - The electronic structure of the $\mathrm{FeFe}$ hydrogenase $\mathrm{H}$-cluster, seen as a molecular dyad. The scheme of the excitations is proposed on the basis of the frontier MO composition of the $\mathrm{H}_{\text {ox }}$-CO model described in ref. ${ }^{84}$. The lower part is adapted with permission from ref ${ }^{84}$, copyright 2016 American Chemical Society.

The above-described $\mathrm{H}$-cluster defines the large family of $\mathrm{FeFe}$ hydrogenases. These enzymes are present in many microorganisms. They differ in terms of protein sequences, quaternary structures and cofactor content ${ }^{87,88}$. The immediate environment of the H-cluster is mostly conserved, although some variations have been observed and may induce unusual catalytic properties $55,85,86$. Non conserved residues that are remote from the active site may 
also affect active site chemistry, as demonstrated using site-directed mutagenesis in the particular case of Clostridium Beijerincki FeFe hydrogenase ${ }^{89}$. They embed a variable number of accessory FeS clusters which are used to mediate long range intramolecular electron transfer: there are 2 accessory clusters in the FeFe hydrogenases from D. desulfuricans (DdHydAB), D. vulgaris (DvHydAB) and M. elsdenii (MeHydA) FeFe hydrogenases, 4 in the FeFe hydrogenases from Clostridium acetobutylicum (Cal), and Clostridium pasteurianum ( $\mathrm{Cpl}$ ), and none in the CrHydA1 enzyme from Chlamydomonas reinhardtii (figure 1).

\section{The effect of light on the CO-inhibited state of FeFe hydrogenases}

The reactivation of the CO-inhibited FeFe hydrogenase by light has been studied since the 1930s, initially to learn about the metal content and structure of the active site and the binding site of hydrogen. More recent investigations of the effect of irradiation have focused on understanding the properties and the reactivity of the active site (Table 1).

\section{Early functional studies of the effect of light on CO-inhibited hydrogenases}

In 1933, Kempner and Kubowitz showed that the production of $\mathrm{H}_{2}$ by Clostridium butyricum is inhibited by $\mathrm{CO}$ and illumination reverses the inhibition ${ }^{90}$. At that time neither the structure of the enzyme nor the presence of nickel and/or iron in the active site had been established; the flash photolysis of $\mathrm{CO}$ had been used to study the reaction of myoglobin with small ligands ${ }^{91,92}$ and the light-dependent CO-inhibition of hydrogenases was taken as an indication of the presence of an iron atom at the active site, as in myoglobin.

The reversal of $\mathrm{CO}$ inhibition by white light was also observed with intact cells and cell-free extracts of other bacteria ${ }^{93-97}$. Some of these early observations are ambiguous because some of the bacteria that were investigated, e.g. D. desulfuricans, produce $\mathrm{FeFe}$ and $\mathrm{NiFe}$ hydrogenases, both of which are light-sensitive in the CO-inhibited state. The effect of irradiation was probably also modulated by the permeability of the biological membranes.

Rudolf K. Thauer and coworkers performed the first kinetic study of FeFe hydrogenases inhibition by $\mathrm{CO}$ in vitro and also observed the reversal of the inhibition by light $^{98}$. The authors qualitatively observed that after exposure to $\mathrm{CO}$, the $\mathrm{H}_{2}$ oxidation activity of the enzyme is ten times greater under the light of a halogen lamp than in the dark, which was interpreted as evidence of the photolysis of the CO-enzyme complex. The effect of light was fully reversible. The rates of binding and release of $\mathrm{CO}$ under illumination were not measured.

\section{Spectroscopic and crystallographic investigations}

EPR and FTIR spectroscopic techniques have later been used to show that illumination affects the structure of the $\mathrm{H}$-cluster in the $\mathrm{H}_{\mathrm{ox}} \mathrm{CO}$ state. Under cryogenic conditions, one $\mathrm{CO}$ ligand is photo-dissociated, but the structure of the photoproduct depends on temperature. At room temperature the illumination allows the exchange between intrinsic and extrinsic $\mathrm{CO}$, demonstrating the dynamics of the $[2 \mathrm{Fe}]_{H}$ site. 


\section{Low temperature}

Peters and Lemon obtained the first crystallographic structure of the FeFe hydrogenase of Clostridium pasteurianum $(\mathrm{Cpl})^{99}$, and in 2000 they reported the effect of irradiating the crystal of the CO-inhibited state with a red laser $(635.8 \mathrm{~nm})$ under a liquid nitrogen stream ${ }^{100}$. The exogenous $\mathrm{CO}$ binds on the axial site of $\mathrm{Fe}_{\mathrm{D}}$ and partial dissociation is observed after irradiation. The difference between the electron density maps evidences an increased distance between the $S$ of a conserved methionine residue and the bridging $\mathrm{CO}$, resulting from an increased electron density on the bridging $\mathrm{CO}$ after the photolysis of the apical $\mathrm{CO}^{100}$.

In the late 1980's, Patil ${ }^{101}$, Kowal $^{102}$ and coworkers had used EPR to examine the effect of light on the enzymes from $D$. vulgaris (DvHydAB) and C. pasteurianum $(\mathrm{Cpl})$, respectively, under cryogenic conditions. Patil and colleagues observed that the $\mathrm{H}_{\mathrm{ox}}-\mathrm{CO}$ EPR signal at $\mathrm{g}=$ 2.06 signal is converted to the rhombic $g=2.10$ signal, assigned to $\mathrm{H}_{\mathrm{ox}}$, upon irradiation with a $200 \mathrm{~W}$ mercury arc lamp at $9 \mathrm{~K}$. Heating the sample to $200 \mathrm{~K}$ gives back the $\mathrm{H}_{\mathrm{ox}}-\mathrm{CO}$ signal, showing that the $\mathrm{CO}$ ligand remains in the environment of the $\mathrm{H}$-cluster and rebinds if the temperature is high enough that the corresponding energy barrier can be overcome. According to Kowal et al., irradiation at $8 \mathrm{~K}$ produces $\mathrm{H}_{\mathrm{ox}}$, but irradiation at $30 \mathrm{~K}$ produces a signal at $\mathrm{g}=2.26,2.12$ and 1.89 , falsely suggesting the presence of a low spin Fe ${ }^{\text {III }}$ center, at a time when the structure of the $\mathrm{H}$-cluster was unknown.

Changes in H-cluster structure have also also been detected using FTIR spectroscopy. Peters, Bagley and coworkers observed that the irradiation of $\mathrm{Cpl} \mathrm{H}_{\mathrm{ox}}-\mathrm{CO}$ with a $300 \mathrm{~W}$ xenon lamp at 6-14 K produces the $\mathrm{H}_{\mathrm{ox}}$ state (which decays back to $\mathrm{H}_{\mathrm{ox}}-\mathrm{CO}$ above $150 \mathrm{~K}$ ), but a second species is produced upon irradiation above $20 \mathrm{~K}$; it is characterized by the loss of the bridging $\mathrm{CO}$ band at $1809 \mathrm{~cm}^{-1}$ and decays above $80 \mathrm{~K}$ by $\mathrm{CO}$ rebinding ${ }^{67}$. The authors hypothesize that the later species gives the $\mathrm{g}=2.26$ rhombic signal in the experiments of Kowal et al. ${ }^{101,102}$, and that the photodissociation involves the bridging or apical CO depending on temperature (see fig. 3). Working with $D$. desulfuricans hydrogenase (DdHydAB), Roseboom et al. also observed by FTIR that illuminating $\mathrm{H}_{\mathrm{ox}}-\mathrm{CO}$ at $15-30 \mathrm{~K}$ with an halogen lamp or with a more intense light (xenon lamp), causes the disappearance of both the bands of extrinsic $\mathrm{CO}$ and of the bridging $\mathrm{CO}$, or only of the bridging $\mathrm{CO}$ in molecules where the extrinsic $\mathrm{CO}$ is already photo-dissociated ${ }^{66}$. The removal of the bridging $\mathrm{CO}$ from $\mathrm{H}_{\mathrm{ox}}-\mathrm{CO}$ at cryogenic temperatures has no effect on the frequencies of the other intrinsic COs and on the charge densities of the irons, again in contrast with the results in ref ${ }^{67}$. It is unclear if the observed differences result from the enzymes from C. pasteurianum and $D$. desulfuricans behaving differently, or the different irradiation times (10 minutes versus 20 minutes to hours) or light power (300 W vs $150 \mathrm{~W}$ ) or lamp emission spectra. Based on an EPR and ENDOR investigation, Lubitz and coworkers concluded that the "second" photoproduct $\left(\mathrm{H}_{\mathrm{LI}}\right)$ is characterized by an unpaired spin density localized on the diiron site, in particular over the $\mathrm{CN}^{-}$ligands, resulting from a structural rearrangement which cannot be merely the dissociation of bridging $\mathrm{CO}^{103}$. In all cases, all the signals obtained after irradiation decay upon warming the sample in the dark at $150 \mathrm{~K}$.

Katz et al. also recently observed by FTIR the photo-dissociation of exogenous CO from the $\mathrm{H}$-cluster of $\mathrm{CrHydA} 1$ after blue light irradiation at $460 \mathrm{~nm}$ and $80 \mathrm{~K}$, mimicking the resonance raman spectroscopy conditions, under which only the $\mathrm{H}_{\mathrm{ox}}$ and $\mathrm{H}_{\text {red }}$ states result ${ }^{104}$. 
Laser irradiation at low temperature of an $\mathrm{H}_{2}$-treated C. reinhardtii $\mathrm{HydA} 1$ sample induces an intramolecular electron transfer from the dinuclear cluster to the $[4 \mathrm{Fe} 4 \mathrm{~S}]_{\mathrm{H}}$ subsite $^{104}$.

Lorent et al. recently studied the effect of light on the production of hydride-bound states under cryogenic conditions, in absence of $\mathrm{CO}^{105}$. The authors use photoactivation in combination with cryogenic infrared (IR) and electron paramagnetic resonance (EPR) spectroscopy to study the [FeFe]-hydrogenase from C. reinhardtii (CrHydA1), discovering two new terminal hydride species.
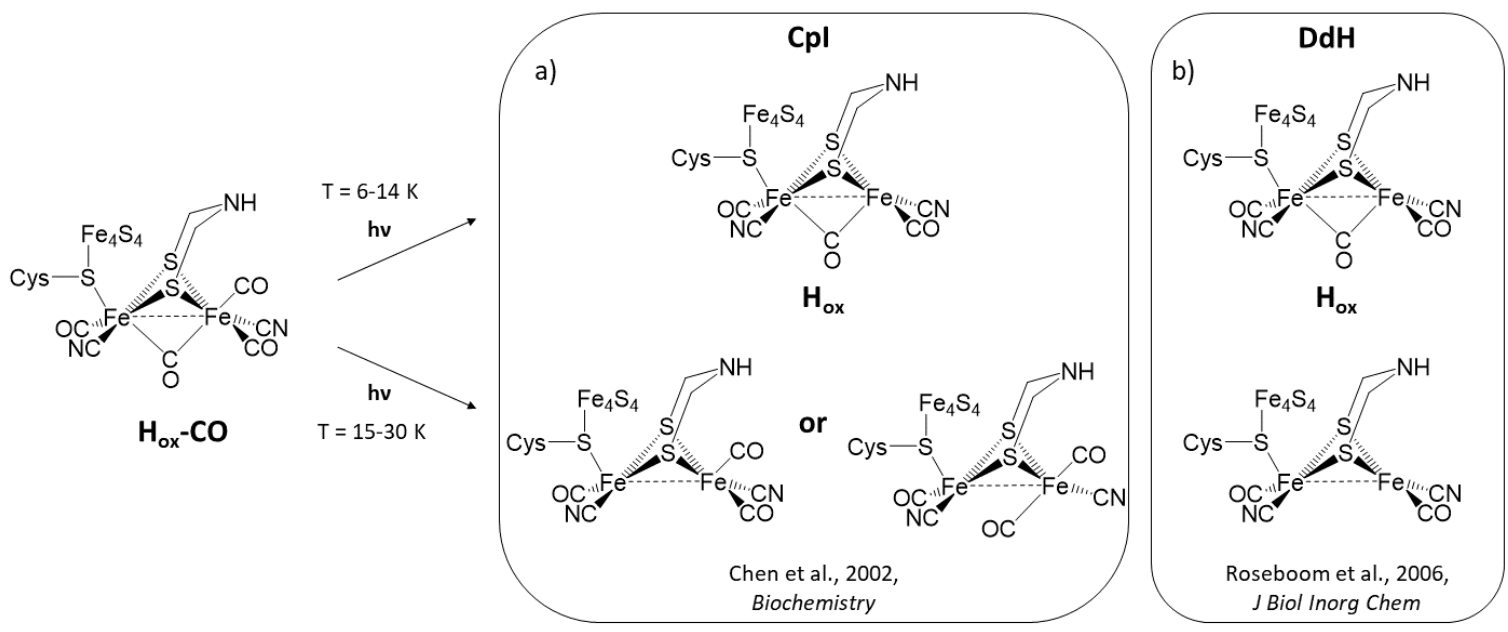

Flgure 3 - Species formed by irradiation of $\mathrm{FeFe}$ hydrogenases inhibited by $\mathrm{CO}$ at cryogenic temperatures, according to Chen ${ }^{67}$ and Roseboom ${ }^{66}$. Irradiation of $\mathrm{H}_{o x}{ }^{-} \mathrm{CO}$ state at temperatures between 30 and $150 \mathrm{~K}$ produces essentially $H_{0 x}$, while no CO photolysis is observed at $T>150 \mathrm{~K}$ due to rapid recombination of the CO ligand. Additionally, all light-induced changes can be completely reversed by warming the sample to $150 \mathrm{~K}$ in the dark.

\section{Room temperature}

In experiments carried at room temperature, Albracht et al. observed that the illumination with an halogen lamp has no effect on the EPR and FTIR spectra of the $\mathrm{H}_{\mathrm{ox}}-\mathrm{CO}$ and $\mathrm{H}_{\text {inact }}$ states, but in samples prepared with ${ }^{13} \mathrm{CO}$ illumination shuffles the two distal $\mathrm{CO}$ ligands bound to $\mathrm{Fe}_{\mathrm{D}}{ }^{59,66}$.

Stripp et al. used this effect to study the dynamics of the $[2 \mathrm{Fe}]_{H}$ site by isotope exchange with real-time attenuated total reflection FTIR (ATR-FTIR) ${ }^{106}$. The exposure of CrHydA1 in the $\mathrm{H}_{\mathrm{ox}}-\mathrm{CO}$ state to exogenous ${ }^{13} \mathrm{CO}$ results in a shift of the IR bands that is ascribed to the exchange of one of the intrinsic $\mathrm{CO}$ ligands on $\mathrm{Fe}_{\mathrm{D}}$ with the labelled ligand. Subsequent irradiation with red light $(640 \mathrm{~nm})$ and then blue light $(460 \mathrm{~nm})$ induces the formation of a cluster binding four labeled ${ }^{13} \mathrm{CO}$ ligands. A difference is observed between C. pasteurianum, D. desulfuricans and C. reinhardtii hydrogenases: red light illumination exchanges the bridging $\mathrm{CO}$ of $\mathrm{Cpl}$ and $\mathrm{DdHydAB}$ hydrogenases, whereas blue light is required to obtain the same effect in the case of CrHydA1. Stripp et al. propose the structures of the different forms from the IR spectra using a DFT model of the H-cluster with truncated cysteines, and larger models that include amino acids around the active site. Regarding the $\mathrm{H}_{\mathrm{ox}}-\mathrm{CO}$ species, these calculations support the presence of the distal $\mathrm{CN}^{-}$ 
ligand in the apical position, instead of the consensual equatorial position. In contrast, other spectroscopic $^{107}$ and DFT studies ${ }^{108-110}$ have considered unlikely the coordination of the distal $\mathrm{CN}^{-}$on the apical binding site.

\section{Kinetics}

The kinetics of $\mathrm{CO}$ binding or release has been examined using time-resolved IR spectroscopy, to focus on rebinding of $\mathrm{CO}$ after photodissociation, and also under turnover conditions by protein film voltammetry, to examine how irradiation affects the kinetics of inhibition by $\mathrm{CO}$.

Regarding the rebinding experiments, Mirmohades et al. ${ }^{111}$ irradiated a C. reinhardtii FeFe hydrogenase 1 sample in the $\mathrm{H}_{\mathrm{ox}}-\mathrm{CO}$ state by flashing a UV laser (10 times $10 \mathrm{~ns}$ flash, $\lambda=355 \mathrm{~nm}$ ), at room temperature, and used time-resolved nanosecond mid-infrared spectroscopy to detect $\mathrm{CO}$ photo-dissociation and rebinding. The quantum yield of conversion is around $10 \%$ for this enzyme, and around $8 \%$ of the total sample was converted into $\mathrm{H}_{\mathrm{ox}}$ after flashing. The kinetics of rebinding was not 1st-order, suggesting that the dissociated $\mathrm{CO}$ may reach several binding sites in the protein before rebinding to $\mathrm{Fe}_{\mathrm{D}}$, and the half-life of the rebinding of $\mathrm{CO}$ was $13 \pm 5 \mathrm{~ms}$.

In protein film voltammetry, the enzyme is adsorbed onto an electrode, and the electrons produced upon $\mathrm{H}_{2}$ oxidation are directly transferred to the electrode. The resulting current is proportional to the turnover frequency, and the variations in current report on any changes in activity ${ }^{112-114}$ which may result from $\mathrm{CO}$ binding or release. A light source can be directed towards the electrode that supports the enzyme, to examine how irradiation affects the activity or the inhibition kinetics ${ }^{112,113}$.

Parkin ${ }^{115}$, Goldet ${ }^{116}$ and coworkers in the Armstrong group have first used this approach to qualitatively evidence the effect of light on the recovery of activity of the CO-inhibited enzyme. The illumination of the enzyme with the white light from a halogen lamp (10 W and $20 \mathrm{~mW} / \mathrm{cm}^{2}$ in ref ${ }^{115}, 150 \mathrm{~W}$ in ref ${ }^{116}$ ) enhances the recovery of activity, but only under oxidizing conditions; no effect is seen at low electrode potential, when the enzyme is evolving $\mathrm{H}_{2}$. No difference was noted between C. acetobutylicum HydA1 and C. reinhardtii HydA1. The rate of the process was not determined.

We also used electrochemistry to examine how light affects the $\mathrm{CO}$ binding and release kinetics, aiming for a quantitative description of the photoreactivity. We irradiated the FeFe hydrogenases from M. elsdenii, C. acetobutylicum and C. reinhardtii (HydA1) adsorbed onto electrodes with monochromatic lasers, varying the wavelength (405, 450, 532 and $635 \mathrm{~nm})$ and the incident power density (from 0 to $60 \mu \mathrm{W} / \mathrm{cm}^{2}$ ). We obtained the values of the CO binding ("in") and release ("out") rate constants using previously developed methods ${ }^{14,117-119}$. We found that irradiation has no effect on the $\mathrm{CO}$ binding rate, but blue or violet light efficiently dissociates the exogenous $\mathrm{CO}$. From the slope of the linear change in $k_{\text {out }}$ against light power, we estimated the value of the molecular absorption cross-section relative to the photodissociation of $\mathrm{CO}$, which appears to be similar to the values deduced from the extinction coefficient of $\mathrm{H}$-cluster biomimetic complexes; this shows that most of the absorbed blue-violet light leads to the dissociation of $\mathrm{CO}$.

We combined the experimental results with the conclusions from TDDFT calculations to obtain an electronic and mechanistic description of the process. The $\mathrm{CO}$ inhibited $\mathrm{H}_{\mathrm{ox}}-\mathrm{CO}$ 
form of the $\mathrm{H}$-cluster is an oversaturated organometallic complex since one of the two $\mathrm{Fe}$ atoms formally counts 19 valence electrons. Our TDDFT calculations ${ }^{120}$ show that $\mathrm{H}_{\mathrm{ox}}-\mathrm{CO}$ absorbs at a lower wavelength than $\mathrm{H}_{\mathrm{ox}}$, and evidence a resulting $\mathrm{CO}$ photolysis pathway. Indeed, starting from the electronic structure of the $\mathrm{H}$-cluster ${ }^{83}$, the $\mathrm{H}_{\mathrm{ox}}-\mathrm{CO}$ calculated spectra showed that only the $\mathrm{Fe}_{4} \mathrm{~S}_{4} \rightarrow \mathrm{Fe}_{2} \mathrm{~S}_{2}$ charge-transfer and $\mathrm{Fe}_{2} \mathrm{~S}_{2}$ localized excitations in the visible light range are active toward $\mathrm{CO}$ dissociation, in agreement with the experimental results. The exploration of the potential energy surfaces of the excited states as a function of the $\mathrm{Fe}-\mathrm{CO}$ bond length clearly evidenced a non-radiative pathway characterized by a series of internal conversions (IC) that end with the release of the $\mathrm{CO}$ in the apical position. Using TDDFT geometry optimizations we also simulated one of these possible pathways for the dissociation of the apical $\mathrm{CO}^{84}$.

\section{Photoinhibition}

Early FTIR and EPR measurements showed DdHydABis damaged by the sunlight or by the white light from a Xe lamp, but not a halogen lamp. In contrast, recent PFV and FTIR studies of $D$. desulfuricans hydrogenase showed that inactivation occurs upon irradiation with a halogen lamp under oxidizing turnover conditions. Regarding $\mathrm{Cal}$ and CrHydA1 hydrogenases, no inactivation was observed upon illumination with a halogen lamp or lasers in the visible range, but UV-B irreversibly inactivates the enzyme under both oxidizing and reducing conditions (Table 1 ).

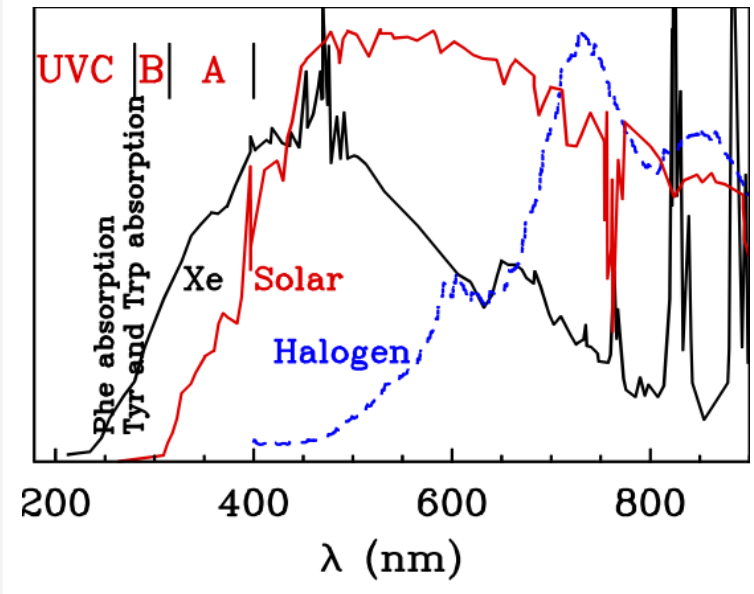

Figure 4 - Emission spectra of sunlight (red), a xenon lamp (black) and a halogen lamp (blue). Reprinted with permission from ref ${ }^{121}$, Copyright 2017 American Chemical Society.

Figure 4 shows the xenon and halogen lamps emission spectra. The halogen lamp spectra has an overall higher emission in the visible range above $600 \mathrm{~nm}$ than the xenon lamp but the latter has some emission peaks in the near-infrared, and higher UV components than the halogen lamp. The power density actually received by the sample also certainly matters ${ }^{84}$, since saturation of light absorption only occurs when the absorption cross section is very large; however, this information is rarely available in research papers.

The first evidence of the detrimental effect of light on FeFe hydrogenase was published by Albracht and coworkers in $2006^{59}$, in an IR and EPR investigation of $D$. desulfuricans hydrogenase $(\mathrm{HydAB})$. At room temperature and upon irradiation with a UV-filtered xenon lamp, the EPR and FTIR ${ }^{66}$ spectra of $D$. desulfuricans $H y d A B$ initially in the $\mathrm{H}_{\mathrm{ox}}$ state show 
contributions from the $\mathrm{H}_{\mathrm{ox}}-\mathrm{CO}$ state, which is a signature of $\mathrm{H}$-cluster degradation: $\mathrm{CO}$ ligands are released from some degraded $\mathrm{H}$-cluster and bind to other, still-intact enzyme molecules. This "cannibalization" process is also observed when the enzyme is exposed to $\mathrm{O}_{2}{ }^{122}$. DdHydAB in the $\mathrm{H}_{\text {red }}$ state was less sensitive to light. Under cryogenic conditions, illumination of the $D$. desulfuricans hydrogenase samples in the $\mathrm{H}_{\mathrm{ox}}-\mathrm{CO}$ state with a xenon lamp leads to the disappearance of both the extrinsic and bridging $\mathrm{CO}$ bands from the FTIR spectra, whereas only the release of the extrinsic $\mathrm{CO}$ is observed using a halogen lamp. The specific effect of the two lamps suggests that the differences between the emission spectra of the halogen and xenon lamp are crucial. Xenon lamps have a UV component, which is almost completely absent in halogen lamps, but the authors used a "glass light guide" that eliminated "most of the UV contribution"66. We can only speculate that the different effects of the lamps are due to the higher intensity of the emission of the xenon lamp in the visible range or to a small fraction of not filtered UV light.

In 2016, Rüdiger and coworkers ${ }^{123}$ also observed the light sensitivity of $D$. desulfuricans hydrogenase at room temperature, using protein film voltammetry and FTIR. The FTIR spectra of $D$. desulfuricans $\mathrm{HydAB}$ after irradiation presented the typical $\mathrm{H}_{\mathrm{ox}}-\mathrm{CO}$ bands previously observed by Albracht et al. ${ }^{59,66}$ In electrochemistry experiments, the authors illuminated the protein film with a $50 \mathrm{~W}$ halogen lamp positioned under the electrochemical glass cell, which we expect should block UV light. Under oxidizing conditions, constant illumination induces an inactivation followed by a partial recovery of the activity; another partial reactivation is observed when the light source is switched off. No such effect is observed under reducing conditions (figure $2 \mathrm{~b}$ in ref ${ }^{123}$ ). The authors propose that the photoinhibition of the enzyme on the electrode is due photodamage and cannibalization, and the subsequent reactivation would result from the dissociation of CO. However, and as pointed out by the authors themselves, the experimental conditions do not allow the small amount of $\mathrm{CO}$ resulting from enzyme degradation to bind to nearby enzyme molecules on the electrode surface. The two-step reactivation, under illumination and after light removal, is not explained.

In the above described experiments performed with $D$. desulfuricans hydrogenase, the role of the emission spectra of the lamp is not clear. Rüdiger et al. observed the inactivation of DdHydAB using a halogen lamp, whereas Albracht et al. observed the photodamage of the same enzyme upon irradiation with a xenon lamp but not with a halogen lamp. In independent electrochemistry experiments, Parkin et al. also saw no photoinhibition of $D$. desulfuricans hydrogenase by irradiating with a halogen lamp ${ }^{115}$ (whose power was lower than that used by Rüdiger et al.).

Regarding the photoinhibition of the enzymes from C. acetobutylicum (HydA1) and C. reinhardtii (HydA1), Goldet and collaborators detected no photoinhibition upon irradiation with a halogen lamp; they only observed that irradiation slightly increases magnitude of the current and do not comment on whether or not it is possible that an increase in activity would result from irradiation heating the graphite electrode ${ }^{116}$. We consider it unlikely that irradiation would significantly perturb the catalytic cycle of hydrogenase: because of the small value of the absorption cross section of the enzyme in the visible range, photon absorption is a very rare event, unless a high power laser is used. 


\begin{tabular}{|c|c|c|c|c|c|}
\hline Reference & Enzyme & source & $\lambda$ & $P$ & $\mathrm{~T}$ \\
\hline Thauer et al, $1974^{98}$ & Cpl & halogen & & $250 \mathrm{~W}$ & RT \\
\hline Patil et al, $1986^{101}$ & DvHydAB & halogen & & $300 \mathrm{~W}$ & Cryo \\
\hline Kowal et al, $1989^{102}$ & Cpl & xenon & & $200 \mathrm{~W}$ & Cryo \\
\hline Lemon et al, $1999^{99}$ & Cpl & laser & $632.8 \mathrm{~nm}$ & & Cryo \\
\hline Chen et al, $2002^{67}$ & Cpl & xenon & & $300 \mathrm{~W}$ & Cryo \\
\hline $\begin{array}{l}\text { Albracht et al, } 2006 \\
\text { Roseboom et al, } 2006^{59,66}\end{array}$ & DdHydAB & $\begin{array}{l}\text { halogen, } \\
\text { xenon }\end{array}$ & & $150 \mathrm{~W}$ & $\begin{array}{l}\text { Cryo } \\
\text { and RT }\end{array}$ \\
\hline Parkin et al, $2006^{115}$ & DdHydAB & halogen & & $10 W$ & RT \\
\hline Goldet et al, $2009^{116}$ & $\begin{array}{l}\text { CrHydA1, } \\
\text { Cal }\end{array}$ & halogen & & $150 \mathrm{~W}$ & RT \\
\hline Silakov et al, $2011^{103}$ & DdHydAB & laser & $355 \mathrm{~nm}$ & & Cryo \\
\hline Katz et al, $2016^{104}$ & CrHydA1 & LED & $460 \mathrm{~nm}$ & & Cryo \\
\hline Senger et al, $2016^{106}$ & Cpl & laser & $\begin{array}{l}460 \mathrm{~nm}, \\
640 \mathrm{~nm}\end{array}$ & & RT \\
\hline Mirmohades et al, $2016^{111}$ & CrHydA1 & laser & $355 \mathrm{~nm}$ & & RT \\
\hline Sensi et al, $2016^{84}$ & $\begin{array}{l}\text { CrHydA1, } \\
\text { Cal, } \\
\text { MeHydA }\end{array}$ & laser & $\begin{array}{l}405,450, \\
532,635 \mathrm{~nm}\end{array}$ & $10 \mathrm{~mW}$ & RT \\
\hline Rodriguez-Macia et al, $2016^{123}$ & DdHydAB & halogen & & $50 \mathrm{~W}$ & RT \\
\hline Sensi et al, $2017^{121}$ & $\begin{array}{l}\text { CrHydA1, } \\
\text { Cal }\end{array}$ & xenon & $\begin{array}{l}\text { UVA, UVB, } \\
\text { white (using } \\
\text { filters) }\end{array}$ & $150 \mathrm{~W}$ & RT \\
\hline Lorent et al, $2020^{105}$ & CrHydA1 & LED & $460 \mathrm{~nm}$ & & Cryo \\
\hline
\end{tabular}

Table 1. Summary of the literature about the effect of light on distinct FeFe hydrogenases, under various conditions of irradiation: wavelength $\lambda$, power $P$, temperature (room temperature, 'RT', or cryogenic conditions, 'Cryo').

On our side, we also used direct electrochemistry to look for evidence of photoinhibition of Cal and CrHydA1. We saw no detrimental effect of laser irradiation at 405, 450, 532 or $635 \mathrm{~nm}$, but using a xenon lamp and various filters, we concluded that UV-B slowly and irreversibly inactivates the enzymes; this occurs under both $\mathrm{H}_{2}$ oxidation and $\mathrm{H}^{+}$reduction conditions when the enzyme is adsorbed onto an electrode, and also when the enzyme is stored in solution. According to time-dependent DFT (TDDFT) calculations, the $\mathrm{H}_{\mathrm{ox}}$ UV-visible spectrum is characterized by the presence of charge-transfer excited states 
involving the intrinsic $\mathrm{CO}$ ligands that can be populated upon absorption in the UV domain. Exploring the $\mathrm{H}_{\mathrm{ox}}$ excited states potential energy surfaces (PES) as a function of the Fe-CO and $\mathrm{Fe}-\mathrm{S}$ bonds lengths of the $[2 \mathrm{Fe}]_{\mathrm{H}}$ subcluster, we observed in silico the dissociation of the terminal $\mathrm{CO}$ ligands. The most stable photo-product has an all-terminal geometry without the bridging $\mathrm{CO}$ and with two equatorial $\mathrm{COs}$, irrespective of the redox state of the initial species. The reduced form of this photo-product could easily form a stable dead-end with a bridging hydride, which we considered the likely structure of the inactive photoproduct ${ }^{121}$.

The reason why DdHydAB is apparently sensitive to white light, unlike homologous hydrogenases, is unknown ${ }^{121}$.

\section{Photochemistry of mimics of the H-cluster}

The hydrogenases scientific community has invested enormous efforts in the search of structural and functional analogues of the $\mathrm{H}$-cluster. Many models have been synthetized, considering the diron $\left[\mathrm{Fe}_{2}(\mathrm{CO})_{6}(\mathrm{pdt})\right]$ model as the parent ${ }^{124,125,126}$. Photochemical activation is a common tool for ligand substitution in this family of complexes ${ }^{124}$. Figure 5 shows three general mechanisms by which $\mathrm{Fe}_{2} \mathrm{~S}_{2}$ models can produce $\mathrm{H}_{2}$.

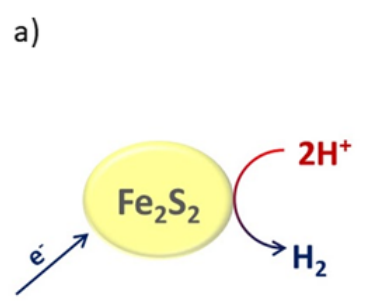

b)

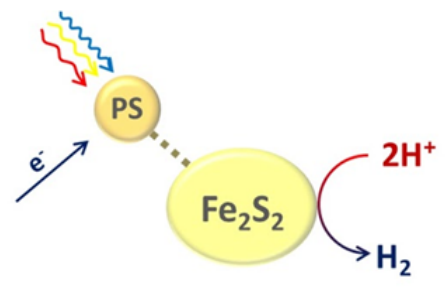

c)

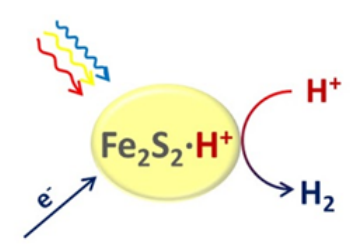

Figure 5. General mechanisms of catalysis and photocatalysis by [FeFe]-hydrogenase binuclear models.

Fig 5a shows $\mathrm{H}_{2}$ production by an $\mathrm{Fe}_{2} \mathrm{~S}_{2}$ model in an acidic solution and in the presence of an electron donor.

A photocatalytic diad system is obtained when this cluster is conjugated to a photosensitizer (PS), such as a classical $\mathrm{Ru}(\mathrm{II})$ or $\mathrm{Pt}(\mathrm{II})$ complex with bis- or tris-dentate pyridine or porphyrins ligands (Fig $5 \mathrm{~b}$ ). ${ }^{25,127} \mathrm{H}_{2}$ can then be produced in the presence of a less reducing electron donor, since the free energy for $\mathrm{H}_{2}$ evolution comes in part from an electron or energy transfer process from PS to the cluster ${ }^{128}$.

An alternative approach consists in using a protonated $\mathrm{Fe}_{2} \mathrm{~S}_{2}$ model that can itself absorb light energy (Fig $5 \mathrm{c}$ ). The advantage is to avoid the sensitization and all issues related to the chemical PS-model conjugation and the quantum yield of the PS-model quenching. The first photocatalyst of this type was the protonated $\mathrm{Fe}_{2}(\mathrm{pdt})(\mu-\mathrm{H})(\mathrm{CO})_{4}(\mathrm{dppv})$ (where dppv= cis-1,2- $\left.\mathrm{C}_{2} \mathrm{H}_{2}\left(\mathrm{PPh}_{2}\right)_{2}\right)$ investigated by Rauchfuss et al. ${ }^{129-131}$ In this case, light absorption induces a loss of the bridging character of the hydride, which is reminiscent of the behavior of the $\mu-\mathrm{CO}$ in the CO-inhibited form of the H-cluster ${ }^{129-131}$. The formation of a terminal hydride is favored by the presence of electron-rich phosphine ligands ${ }^{132}$. 


\begin{tabular}{|c|c|c|c|}
\hline \multirow[b]{2}{*}{ Reference } & \multirow[b]{2}{*}{$\lambda(\mathrm{nm})$} & \multicolumn{2}{|c|}{$\mathrm{Fe}_{2}(\mathrm{~L})_{6}($ bridging ligand $)$} \\
\hline & & Ligands & bridging ligand \\
\hline Ridley et al., $2008{ }^{133}$ & 350 & $\mathrm{CO}$ & pdt \\
\hline Brown-McDonald et al., $2009{ }^{134}$ & 365 & $\mathrm{CO}$ & pdt \\
\hline Bertini et al., $2009^{135}$ & - & $\mathrm{CO}$ & pdt \\
\hline Strewart et al., $2010^{136}$ & 350 & $\mathrm{CO}$ & pdt \\
\hline Kaziannis et al., $2010^{137}$ & 355,435 & $\mathrm{CO}$ & pdt \\
\hline Marhenke et al., $2011^{138}$ & 365 & $\mathrm{CO}$ & pdt \\
\hline Stromberg et al., $2011{ }^{139}$ & - & $\mathrm{CO}$ & pdt,edt \\
\hline Bingaman et al., $2012^{140}$ & $266,355,532$ & $\mathrm{CO}$ & pdt \\
\hline Muhammad et al., $2012^{141}$ & 355 & $\mathrm{CO}$ & pdt \\
\hline Kania et al., $2012^{142}$ & 355 & $4 \mathrm{CO}, 2 \mathrm{PMe}_{3}$ & pdt \\
\hline Johnson et al., $2013^{143}$ & 355,532 & $4 \mathrm{CO}, 2 \mathrm{PMe}_{3}$ & pdt \\
\hline Bertini et al., $2014{ }^{144}$ & - & $\mathrm{CO}$ & pdt \\
\hline Caplins et al., $2014{ }^{145}$ & 400 & $\mathrm{CO}$ & bdt \\
\hline Thornley et al., $2015^{146}$ & 330,400 & $\mathrm{CO}$ & pdt \\
\hline Goy et al., $2016{ }^{147}$ & - & $\mathrm{CO}$ & fluorene; silafluorene \\
\hline Hunt et al., $20166^{148}$ & 365 & $4 \mathrm{CO}, 2 \mathrm{CN}^{-}$ & pdt \\
\hline Bertini et al., $2018^{149}$ & - & $4 \mathrm{CO}, 2 \mathrm{PMe}_{3}$ & edt \\
\hline Meyer et al., $2018^{150}$ & $266,355,532$ & $4 \mathrm{CO}, 2 \mathrm{PMe}_{3}$ & edt \\
\hline Stromberg et al., $2018^{151}$ & 266,400 & $4 \mathrm{CO}, 2 \mathrm{CN}^{-}$ & pdt \\
\hline Thornley et al., $2019{ }^{152}$ & 200,525 & 4CO, bipy/phen & pdt \\
\hline Bertini et al., $2021^{153}$ & - & $\mathrm{CO}, \mu \mathrm{CO}$ & pdt \\
\hline Meyers et al., $2021^{154}$ & 400 & $\begin{array}{l}\text { mono substituted } \\
\mathrm{CN}^{-}\end{array}$ & edt,pdt \\
\hline
\end{tabular}

Table 2 - Summary of the literature about the photochemistry of the $\mathrm{Fe}_{2} \mathrm{~S}_{2}$ model complexes (pdt=propandithiolate ; edt=etandithiolate ; bipy=2,2'-bipyridine ; phen=1,10-phenanthroline; $\mathrm{PMe}_{3}=$ trimethylphosphine). 
Besides the design and investigation of photocatalytic systems, an interest has grown in photochemistry of the simple $\mathrm{Fe}_{2} \mathrm{~S}_{2}$ model. Starting with the investigation of $\mathrm{Fe}_{2}(\mathrm{CO})_{6}(\mathrm{pdt})$ in $2008,{ }^{133}$ many models with the general formula $\mathrm{Fe}_{2}(\mathrm{CO})_{4}(\mathrm{~L})_{2}$ (bridging ligand) have been studied (Table 2). The synthetic $\mathrm{Fe}(\mathrm{CO})_{4}(\mathrm{CN})_{2}(\mathrm{adt})$ compound (used for the in vitro reconstitution of [FeFe]-hydrogenases) is catalytically inert ${ }^{155,156}$, but the closely related $\mathrm{Fe}(\mathrm{CO})_{4}(\mathrm{CN})_{2}(\mathrm{pdt})$ is active in $\mathrm{H}_{2}$ photoproduction using $\left[\mathrm{Ru}(\mathrm{bpy})_{3}\right]^{2+}$ as photosensitizer and sodium ascorbate as sacrificial electron donor, upon irradiation with visible light $(\lambda>400$ $\mathrm{nM})^{156,157(\text { (Artero et al. 2015). }}$

The main focus of the photochemical studies was on the ultrafast $(<1 \mathrm{~ns})$ photodynamics of the low-energy excitation, which is mainly dominated by $\mathrm{CO}$ photolysis, as is usual in metal-carbonyl complexes. The aim was to understand the effect of the ligands on the electronic properties of the model in relation to the nature of the photoproducts. The photostability of the models is crucial, if the goal is to wire them to photosensitizers for $\mathrm{H}_{2}$ photoproduction. Flash photolysis kinetics, ultrafast pump/probe time-resolved IR (TRIR) spectroscopy and quantum chemistry calculations have been used to characterize the non-radiative transitions that occur upon UV-Vis light absorption.

The TRIR investigation of $\mathrm{Fe}_{2} \mathrm{~S}_{2}$ 18-electron models evidenced at least one ultrafast $\mathrm{CO}$ dissociation process, with the formation of an 16-electron intermediate species, whose life time depends on the chemical nature of the ligands (e.g. 25 ps in the case of a phen substituted model ${ }^{152}$ and much longer for a cyano-functionalized model ${ }^{151}$ ). TDDFT calculations ${ }^{144}$ suggests that dissociation after excitation in the UV domain results from the population of a dissociative $\mathrm{Fe} \rightarrow \mathrm{CO}$ charge transfer (CT) state, which involves an equatorial CO ligand.

When $\mathrm{Fe}_{2}(\mathrm{CO})_{4}(\mathrm{~L})_{2}$ (bridging ligand) models are considered, ligand isomerization is observed, which is due to the concomitant $\mathrm{CO}$ dissociation and $\mathrm{Fe}-\mathrm{S}$ bond breaking during the non-radiative decay of the first excited state to the ground state ${ }^{149,150}$. The latter result is reminiscent of the photo-inhibition of the enzyme, where photochemical channels are populated when the enzyme is irradiated in the UV range. After CO photolysis, the formation of a long lived solvent adduct is observed ${ }^{141}$, as in the case of the mono cyano substituted models ${ }^{154}$, and geminate recombination gives back the initial model compound.

The excited state properties of the $\mathrm{CO}$ inhibited models have been investigated only theoretically, because over-saturated 19 electron complexes are not stable enough to be synthesized (see however ref. ${ }^{158}$ ). According to TDDFT calculations, the $\mathrm{Fe}_{2}(\mathrm{CO})_{6}(\mu-\mathrm{CO})(\mathrm{pdt})$ complex, a model of the $\mathrm{H}_{\mathrm{ox}}-\mathrm{CO}$ form of the $\mathrm{H}$-cluster, photo-releases a terminal $\mathrm{CO}$ after excitation in the visible domain in a lower energy range than observed with $\mathrm{H}_{\mathrm{ox}}$ models ${ }^{153}$.

\section{Conclusions}

The investigation of the photochemistry of the H-cluster biomimetic models has been important not only to design a better and efficient system for hydrogen photo-production, but also to shed light on the functionality of the active site itself. The spectroscopic, electrochemical and DFT studies on the photochemistry of FeFe hydrogenases contributed 
not only to improve the development of hydrogen photo-production but also to obtain a fine description of the $\mathrm{H}$-cluster electronic structure.

Our survey of $\mathrm{H}$-cluster biomimetic model photochemistry has revealed that most of the complexes are photosensitive in the UV domain, as are the enzymes, and undergo ultrafast photodissociation of a terminal $\mathrm{CO}$ ligand. Following this, the unsaturated models form a solvent adduct that slowly decays to the initial model. The scrambling of the ligands is often observed along the vibrational cooling pathway, this process being favored by the transient vacancy of the $\mathrm{CO}$ ligand and the weakening of a Fe-S bond. The main difference between the photodynamics of the $\mathrm{H}$-cluster and of its models comes from the ability of the latter to form a solvent adduct, whereas the $\mathrm{H}$-cluster is shielded from the solvent.

The investigation on $\mathrm{CO}$ inhibited models has shown that the presence of an exogenous CO ligand lowers the energy range of the MLCT bands and of the CO photolysis channels. For this reason it appears that the ligand $\mathrm{CO}$ protects the $[2 \mathrm{Fe}]_{H}$ cluster since it is able to capture visible light, after which the system decays through photo-dissociative channels that involve a CO ligand, thus preventing irreversible photo-damage.

The literature on the photochemistry of the enzymes is related to photo processes that occur on longer time scales, and is relevant to the practical use of hydrogenases in $\mathrm{H}_{2}$ photoproduction systems.

Overall, the literature is not fully consistent and difficult to assess because of the lack of precise report of experimental design and control experiments, regarding e.g. heating and photoelectric effects, or the details about the light sources and power, and the nature of the transparent materials the containers and electrochemical cells are made of. However, clear differences in photosensitivity have been observed between homologous FeFe hydrogenases, the enzyme from $D$. desulfuricans being particularly fragile in this respect. It is remarkable that this enzyme is also more $\mathrm{O}_{2}$ sensitive than e.g. clostridial $\mathrm{FeFe}$ hydrogenase ${ }^{14}$, and sensitive to inhibition by sulfide whereas Cpl hydrogenase apparently is not ${ }^{70}$. These variations are puzzling, considering that all these enzymes embed the same $\mathrm{H}$-cluster, whose environment is very conserved. These observations demonstrate that structural details must influence the resistance to photochemical stress of FeFe hydrogenases. Such long distance effects are difficult to investigate. Regarding oxidative stress, we recently demonstrated that residues that are remote from the active site may change the flexibility of the protein and the reactivity in the 1st coordination sphere of the distal Fe. ${ }^{89}$

\section{Acknowledgements}

The work in Marseille was supported by CNRS, Aix Marseille Université and the Excellence Initiative of Aix-Marseille University - $A^{*}$ MIDEX, a French "Investissements d'Avenir" programme (ANR-11-IDEX-0001-02). The French authors are part of the French bioinorganic chemistry network (www.frenchbic.cnrs.fr).

\section{Bibliography}

1 D.-H. Kim and M.-S. Kim, Bioresour. Technol., 2011, 102, 8423-8431.

2 J. Turner, G. Sverdrup, M. K. Mann, P.-C. Maness, B. Kroposki, M. Ghirardi, R. J. Evans and D. Blake, Int. J. 
Energy Res., 2008, 32, 379-407.

3 A. Latifi, L. Avilan and M. Brugna, Appl. Microbiol. Biotechnol., 2019, 103, 567-575.

4 B. M. Hoffman, D. Lukoyanov, Z.-Y. Yang, D. R. Dean and L. C. Seefeldt, Chem. Rev., 2014, 114, 4041-4062.

5 Y. Hu and M. W. Ribbe, Chembiochem, 2020, 21, 1668-1670.

6 S. Kosourov, M. Böhm, M. Senger, G. Berggren, K. Stensjö, F. Mamedov, P. Lindblad and Y. Allahverdiyev, Physiol. Plant., , DOI:10.1111/ppl.13428.

7 B. Esper, A. Badura and M. Rögner, Trends Plant Sci., 2006, 11, 543-549.

8 W. Khetkorn, R. P. Rastogi, A. Incharoensakdi, P. Lindblad, D. Madamwar, A. Pandey and C. Larroche, Bioresour. Technol., 2017, 243, 1194-1206.

9 M. L. Ghirardi, Photosynth. Res., 2015, 125, 383-393.

10 C. Cassier-Chauvat, T. Veaudor and F. Chauvat, Int. J. Mol. Sci., 2014, 15, 19938-19951.

11 J. B. McKinlay and C. S. Harwood, Curr. Opin. Biotechnol., 2010, 21, 244-251.

12 A. Abou Hamdan, P.-P. Liebgott, V. Fourmond, O. Gutiérrez-Sanz, A. L. De Lacey, P. Infossi, M. Rousset, S. Dementin and C. Léger, Proc. Natl. Acad. Sci. U. S. A., 2012, 109, 19916-19921.

13 P.-P. Liebgott, A. L. de Lacey, B. Burlat, L. Cournac, P. Richaud, M. Brugna, V. M. Fernandez, B. Guigliarelli, M. Rousset, C. Léger and S. Dementin, J. Am. Chem. Soc., 2011, 133, 986-997.

14 P.-P. Liebgott, F. Leroux, B. Burlat, S. Dementin, C. Baffert, T. Lautier, V. Fourmond, P. Ceccaldi, C. Cavazza, I. Meynial-Salles, P. Soucaille, J. C. Fontecilla-Camps, B. Guigliarelli, P. Bertrand, M. Rousset and C. Léger, Nat. Chem. Biol., 2010, 6, 63-70.

15 M. L. Ghirardi, M. C. Posewitz, P.-C. Maness, A. Dubini, J. Yu and M. Seibert, Annu. Rev. Plant Biol., 2007, 58, 71-91.

16 O. Kruse and B. Hankamer, Curr. Opin. Biotechnol., 2010, 21, 238-243.

17 A. Dubini and M. L. Ghirardi, Photosynth. Res., 2015, 123, 241-253.

18 A. Magnuson, M. Anderlund, O. Johansson, P. Lindblad, R. Lomoth, T. Polivka, S. Ott, K. Stensjö, S. Styring, V. Sundström and L. Hammarström, Acc. Chem. Res., 2009, 42, 1899-1909.

19 D. Gust, T. A. Moore and A. L. Moore, Acc. Chem. Res., 2009, 42, 1890-1898.

20 J. Barber and P. D. Tran, J. R. Soc. Interface, 2013, 10, 20120984.

21 A. Bachmeier and F. Armstrong, Curr. Opin. Chem. Biol., 2015, 25, 141-151.

22 D. Adam, L. Bösche, L. Castañeda-Losada, M. Winkler, U.-P. Apfel and T. Happe, ChemSusChem, 2017, 10, 894-902.

23 N. Kornienko, J. Z. Zhang, K. K. Sakimoto, P. Yang and E. Reisner, Nat. Nanotechnol., 2018, 13, $890-899$.

24 K. A. Brown and P. W. King, Photosynth. Res., 2020, 143, 193-203.

25 R. Lomoth and S. Ott, Dalton Trans., 2009, 9952-9959.

26 A. Kanygin, Y. Milrad, C. Thummala, K. Reifschneider, P. Baker, P. Marco, I. Yacoby and K. E. Redding, Energy Environ. Sci., 2020, 13, 2903-2914.

27 H. Kudoh and K. Sonoike, Planta, 2002, 215, 541-548.

28 H. V. Scheller and A. Haldrup, Planta, 2005, 221, 5-8.

29 Biochimica et Biophysica Acta (BBA) - Bioenergetics, 2012, 1817, 209-217.

30 C. Sicora, Z. Máté and I. Vass, Photosynth. Res., 2003, 75, 127-137.

31 N. Plumeré and M. M. Nowaczyk, in Biophotoelectrochemistry: From Bioelectrochemistry to Biophotovoltaics, Springer, Cham, 2016, pp. 111-136.

32 F. Zhao, S. Hardt, V. Hartmann, H. Zhang, M. M. Nowaczyk, M. Rögner, N. Plumeré, W. Schuhmann and F. Conzuelo, Nat. Commun., 2018, 9, 1973.

33 F. A. Armstrong and J. C. Fontecilla-Camps, Science, 2008, 321, 498-499.

34 S. Shima, O. Pilak, S. Vogt, M. Schick, M. S. Stagni, W. Meyer-Klaucke, E. Warkentin, R. K. Thauer and U. Ermler, Science, 2008, 321, 572-575.

35 E. J. Lyon, S. Shima, G. Buurman, S. Chowdhuri, A. Batschauer, K. Steinbach and R. K. Thauer, Eur. J. Biochem., 2004, 271, 195-204.

36 T. Wagner, G. Huang, U. Ermler and S. Shima, Angew. Chem. Weinheim Bergstr. Ger., 2018, 130, $15276-15279$.

37 H. Osuka, Y. Shomura, H. Komori, N. Shibata, S. Nagao, Y. Higuchi and S. Hirota, Biochem. Biophys. Res. Commun., 2013, 430, 284-288.

38 P. Kellers, M.-E. Pandelia, L. J. Currell, H. Görner and W. Lubitz, Phys. Chem. Chem. Phys., 2009, 11, 8680-8683.

39 F. Dole, M. Medina, C. More, R. Cammack, P. Bertrand and B. Guigliarelli, Biochemistry, 1996, 35, 16399-16406.

40 H. Tai, K. Nishikawa, S. Inoue, Y. Higuchi and S. Hirota, J. Phys. Chem. B, 2015, 119, 13668-13674

41 M. Kampa, M.-E. Pandelia, W. Lubitz, M. van Gastel and F. Neese, J. Am. Chem. Soc., 2013, 135, 3915-3925.

42 M.-E. Pandelia, H. Ogata, L. J. Currell, M. Flores and W. Lubitz, J. Biol. Inorg. Chem., 2009, 14, $1227-1241$.

43 H. Tai, L. Xu, S. Inoue, K. Nishikawa, Y. Higuchi and S. Hirota, Phys. Chem. Chem. Phys., 2016, 18, 22025-22030.

44 M.-E. Pandelia, P. Infossi, M. T. Giudici-Orticoni and W. Lubitz, Biochemistry, 2010, 49, 8873-8881.

45 K. A. Bagley, C. J. Van Garderen, M. Chen, E. C. Duin, S. P. Albracht and W. H. Woodruff, Biochemistry, 1994, 33, 9229-9236. 
46 M.-E. Pandelia, H. Ogata, L. J. Currell, M. Flores and W. Lubitz, Biochim. Biophys. Acta, 2010, 1797, 304-313.

47 S. J. George, S. Kurkin, R. N. F. Thorneley and S. P. J. Albracht, Biochemistry, 2004, 43, 6808-6819.

48 H. Tai, K. Nishikawa, Y. Higuchi, Z.-W. Mao and S. Hirota, Angew. Chem. Int. Ed Engl., 2019, 58, 13285-13290.

49 R. Hidalgo, P. A. Ash, A. J. Healy and K. A. Vincent, Angew. Chem. Int. Ed Engl., 2015, 54, 7110-7113.

50 A. Ciaccafava, C. Hamon, P. Infossi, V. Marchi, M.-T. Giudici-Orticoni and E. Lojou, Phys. Chem. Chem. Phys., 2013, 15, 16463-16467.

51 H. Tai, L. Xu, K. Nishikawa, Y. Higuchi and S. Hirota, Chem. Commun. , 2017, 53, 10444-10447.

52 C. Lorent, V. Pelmenschikov, S. Frielingsdorf, J. Schoknecht, G. Caserta, Y. Yoda, H. Wang, K. Tamasaku, O. Lenz, S. P. Cramer, M. Horch, L. Lauterbach and I. Zebger, Angew. Chem. Int. Ed Engl., , DOI:10.1002/anie.202100451.

53 J. C. Fontecilla-Camps, A. Volbeda, C. Cavazza and Y. Nicolet, Chem. Rev., 2007, 107, 4273-4303.

54 J. Photochem. Photobiol. C: Photochem. Rev., 2017, 33, 1-26.

55 H. Land, M. Senger, G. Berggren and S. T. Stripp, ACS Catal., 2020, 10, 7069-7086.

56 D. L. Erbes, R. H. Burris and W. H. Orme-Johnson, Proc. Natl. Acad. Sci. U. S. A., 1975, 72, 4795-4799.

57 A. J. Pierik, M. Hulstein, W. R. Hagen and S. P. Albracht, Eur. J. Biochem., 1998, 258, 572-578.

58 F. M. Rusnak, M. W. Adams, L. E. Mortenson and E. Münck, J. Biol. Chem., 1987, 262, 38-41.

59 S. P. J. Albracht, W. Roseboom and E. C. Hatchikian, J. Biol. Inorg. Chem., 2006, 11, 88-101.

60 B. J. Lemon and J. W. Peters, Biochemistry, 1999, 38, 12969-12973.

61 A. Adamska-Venkatesh, D. Krawietz, J. Siebel, K. Weber, T. Happe, E. Reijerse and W. Lubitz, J. Am. Chem. Soc., 2014, 136, 11339-11346.

62 M. Winkler, M. Senger, J. Duan, J. Esselborn, F. Wittkamp, E. Hofmann, U.-P. Apfel, S. T. Stripp and T. Happe, Nat. Commun., 2017, 8, 16115.

63 D. W. Mulder, Y. Guo, M. W. Ratzloff and P. W. King, J. Am. Chem. Soc., 2017, 139, 83-86.

64 E. J. Reijerse, C. C. Pham, V. Pelmenschikov, R. Gilbert-Wilson, A. Adamska-Venkatesh, J. F. Siebel, L. B. Gee, Y. Yoda, K. Tamasaku, W. Lubitz, T. B. Rauchfuss and S. P. Cramer, J. Am. Chem. Soc., 2017, 139, 4306-4309.

65 A. Adamska, A. Silakov, C. Lambertz, O. Rüdiger, T. Happe, E. Reijerse and W. Lubitz, Angew. Chem. Int. Ed Engl., 2012, 51, 11458-11462.

66 W. Roseboom, A. L. De Lacey, V. M. Fernandez, E. C. Hatchikian and S. P. J. Albracht, J. Biol. Inorg. Chem., 2006, 11, 102-118.

67 Z. Chen, B. J. Lemon, S. Huang, D. J. Swartz, J. W. Peters and K. A. Bagley, Biochemistry, 2002, 41, 2036-2043.

68 P. Rodríguez-Maciá, L. M. Galle, R. Bjornsson, C. Lorent, I. Zebger, Y. Yoda, S. P. Cramer, S. DeBeer, I. Span and J. A. Birrell, Angew. Chem. Int. Ed Engl., 2020, 59, 16786-16794.

69 C. Baffert, M. Demuez, L. Cournac, B. Burlat, B. Guigliarelli, P. Bertrand, L. Girbal and C. Léger, Angew. Chem. Int. Ed., 2008, 47, 2052-2054.

70 P. Rodríguez-Maciá, E. J. Reijerse, M. van Gastel, S. DeBeer, W. Lubitz, O. Rüdiger and J. A. Birrell, J. Am. Chem. Soc., 2018, 140, 9346-9350.

71 A. A. Oughli, S. Hardt, O. Rüdiger, J. A. Birrell and N. Plumeré, Chem. Commun. , 2020, 56, 9958-9961.

72 A. Kubas, C. Orain, D. De Sancho, L. Saujet, M. Sensi, C. Gauquelin, I. Meynial-Salles, P. Soucaille, H. Bottin, C. Baffert, V. Fourmond, R. B. Best, J. Blumberger and C. Léger, Nat. Chem., 2017, 9, 88-95.

73 C. Sommer, A. Adamska-Venkatesh, K. Pawlak, J. A. Birrell, O. Rüdiger, E. J. Reijerse and W. Lubitz, J. Am. Chem. Soc., 2017, 139, 1440-1443.

74 S. Rumpel, C. Sommer, E. Reijerse, C. Farès and W. Lubitz, J. Am. Chem. Soc., 2018, 140, 3863-3866.

75 D. W. Mulder, M. W. Ratzloff, M. Bruschi, C. Greco, E. Koonce, J. W. Peters and P. W. King, J. Am. Chem. Soc., 2014, 136, 15394-15402.

76 L. S. Mészáros, P. Ceccaldi, M. Lorenzi, H. J. Redman, E. Pfitzner, J. Heberle, M. Senger, S. T. Stripp and G. Berggren, Chem. Sci., 2020, 11, 4608-4617.

77 D. W. Mulder, M. W. Ratzloff, E. M. Shepard, A. S. Byer, S. M. Noone, J. W. Peters, J. B. Broderick and P. W. King, J. Am. Chem. Soc., 2013, 135, 6921-6929.

78 A. T. Fiedler and T. C. Brunold, Inorg. Chem., 2005, 44, 9322-9334.

79 A. Silakov, E. J. Reijerse, S. P. J. Albracht, E. C. Hatchikian and W. Lubitz, J. Am. Chem. Soc., 2007, 129, 11447-11458.

80 W. Lubitz, H. Ogata, O. Rüdiger and E. Reijerse, Chem. Rev., 2014, 114, 4081-4148.

81 M. Bruschi, C. Greco, P. Fantucci and L. De Gioia, Inorg. Chem., 2008, 47, 6056-6071.

82 C. V. Popescu and E. Münck, J. Am. Chem. Soc., 1999, 121, 7877-7884.

83 M. Bruschi, C. Greco, L. Bertini, P. Fantucci, U. Ryde and L. De Gioia, J. Am. Chem. Soc., 2010, 132, $4992-4993$.

84 M. Sensi, C. Baffert, C. Greco, G. Caserta, C. Gauquelin, L. Saujet, M. Fontecave, S. Roy, V. Artero, P. Soucaille, I. Meynial-Salles, H. Bottin, L. de Gioia, V. Fourmond, C. Léger and L. Bertini, J. Am. Chem. Soc., 2016, 138, 13612-13618.

85 H. Land, A. Sekretareva, P. Huang, H. J. Redman, B. Németh, N. Polidori, L. S. Mészáros, M. Senger, S. T. Stripp and G. Berggren, Chem. Sci., 2020, 11, 12789-12801.

86 N. Chongdar, J. A. Birrell, K. Pawlak, C. Sommer, E. J. Reijerse, O. Rüdiger, W. Lubitz and H. Ogata, J. Am. 
Chem. Soc., 2018, 140, 1057-1068.

87 S. Poudel, M. Tokmina-Lukaszewska, D. R. Colman, M. Refai, G. J. Schut, P. W. King, P.-C. Maness, M. W. W. Adams, J. W. Peters, B. Bothner and E. S. Boyd, Biochim. Biophys. Acta, 2016, 1860, 1910-1921.

88 M. Calusinska, T. Happe, B. Joris and A. Wilmotte, Microbiology, 2010, 156, 1575-1588.

89 M. Winkler, J. Duan, A. Rutz, C. Felbek, L. Scholtysek, O. Lampret, J. Jaenecke, U.-P. Apfel, G. Gilardi, F. Valetti, V. Fourmond, E. Hofmann, C. Léger and T. Happe, Nat. Commun., 2021, 12, 756.

90 W. Kempner and F. Kubowitz, Biochem. Z., 1933, 265, 245-252.

91 H. Hartridge and F. J. W. Roughton, Proceedings of the Royal Society B: Biological Sciences, 1923, 94, 336-367.

92 Q. H. Gibson, J. Physiol., 1956, 134, 112-122.

93 H. D. Peck, A. S. Pietro and H. Gest, Proceedings of the National Academy of Sciences, 1956, 42, 13-19.

94 L. Purec, A. I. Krasna and D. Rittenberg, Biochemistry, 1962, 1, 270-275.

95 J. C. Sadana and D. Rittenberg, Proc. Natl. Acad. Sci. U. S. A., 1963, 50, 900-904.

96 L. Purec and A. I. Krasna, Proceedings of the National Academy of Sciences, 1967, 57, 1416-1421.

97 L. Purec and A. I. Krasna, Biochemistry, 1968, 7, 51-55.

98 R. K. Thauer, B. Käufer, M. Zähringer and K. Jungermann, Eur. J. Biochem., 1974, 42, 447-452.

99 J. W. Peters, W. N. Lanzilotta, B. J. Lemon and L. C. Seefeldt, Science, 1998, 282, 1853-1858.

100 B. J. Lemon and J. W. Peters, J. Am. Chem. Soc., 2000, 122, 3793-3794.

101 D. S. Patil, M. H. Czechowski, B. H. Huynh, J. LeGall, H. D. Peck Jr and D. V. DerVartanian, Biochem. Biophys. Res. Commun., 1986, 137, 1086-1093.

102 A. T. Kowal, M. W. Adams and M. K. Johnson, J. Biol. Chem., 1989, 264, 4342-4348.

103 A. Silakov, E. J. Reijerse and W. Lubitz, Eur. J. Inorg. Chem., 2011, 2011, 1056-1066.

104 S. Katz, J. Noth, M. Horch, H. S. Shafaat, T. Happe, P. Hildebrandt and I. Zebger, Chem. Sci., 2016, 7, 6746-6752.

105 C. Lorent, S. Katz, J. Duan, C. J. Kulka, G. Caserta, C. Teutloff, S. Yadav, U.-P. Apfel, M. Winkler, T. Happe, M. Horch and I. Zebger, J. Am. Chem. Soc., 2020, 142, 5493-5497.

106 M. Senger, S. Mebs, J. Duan, F. Wittkamp, U.-P. Apfel, J. Heberle, M. Haumann and S. T. Stripp, Proc. Natl. Acad. Sci. U. S. A., 2016, 113, 8454-8459.

107 E. Reijerse, J. A. Birrell and W. Lubitz, J. Phys. Chem. Lett., 2020, 11, 4597-4602.

108 C. Greco, M. Bruschi, J. Heimdal, P. Fantucci, L. De Gioia and U. Ryde, Inorg. Chem., 2007, 46, 7256-7258.

109 C. Greco, M. Bruschi, P. Fantucci, U. Ryde and L. De Gioia, Chemistry - A European Journal, 2011, 17, 1954-1965.

110 M. Bruschi, C. Greco, M. Kaukonen, P. Fantucci, U. Ryde and L. De Gioia, Angew. Chem. Int. Ed., 2009, 48, 3503-3506.

111 M. Mirmohades, A. Adamska-Venkatesh, C. Sommer, E. Reijerse, R. Lomoth, W. Lubitz and L. Hammarström, J. Phys. Chem. Lett., 2016, 7, 3290-3293.

112 M. Sensi, M. del Barrio, C. Baffert, V. Fourmond and C. Léger, Current Opinion in Electrochemistry, 2017, 5, 135-145.

113 M. Del Barrio, M. Sensi, C. Orain, C. Baffert, S. Dementin, V. Fourmond and C. Léger, Acc. Chem. Res., 2018, 51, 769-777.

114 C. Léger and P. Bertrand, Chem. Rev., 2008, 108, 2379-2438.

115 A. Parkin, C. Cavazza, J. C. Fontecilla-Camps and F. A. Armstrong, J. Am. Chem. Soc., 2006, 128, 16808-16815.

116 G. Goldet, C. Brandmayr, S. T. Stripp, T. Happe, C. Cavazza, J. C. Fontecilla-Camps and F. A. Armstrong, J. Am. Chem. Soc., 2009, 131, 14979-14989.

117 M. G. Almeida, C. M. Silveira, B. Guigliarelli, P. Bertrand, J. J. G. Moura, I. Moura and C. Léger, FEBS Lett., 2007, 581, 284-288.

118 C. Baffert, L. Bertini, T. Lautier, C. Greco, K. Sybirna, P. Ezanno, E. Etienne, P. Soucaille, P. Bertrand, H. Bottin, I. Meynial-Salles, L. De Gioia and C. Léger, J. Am. Chem. Soc., 2011, 133, 2096-2099.

119 F. Leroux, S. Dementin, B. Burlat, L. Cournac, A. Volbeda, S. Champ, L. Martin, B. Guigliarelli, P. Bertrand, J. Fontecilla-Camps, M. Rousset and C. Léger, Proc. Natl. Acad. Sci. U. S. A., 2008, 105, 11188-11193.

120 L. Bertini, C. Greco, M. Bruschi, P. Fantucci and L. De Gioia, Organometallics, 2010, 29, 2013-2025.

121 M. Sensi, C. Baffert, L. Fradale, C. Gauquelin, P. Soucaille, I. Meynial-Salles, H. Bottin, L. de Gioia, M. Bruschi, V. Fourmond, C. Léger and L. Bertini, ACS Catalysis, 2017, 7, 7378-7387.

122 K. D. Swanson, M. W. Ratzloff, D. W. Mulder, J. H. Artz, S. Ghose, A. Hoffman, S. White, O. A. Zadvornyy, J. B. Broderick, B. Bothner, P. W. King and J. W. Peters, J. Am. Chem. Soc., 2015, 137, 1809-1816.

123 P. Rodríguez-Maciá, J. A. Birrell, W. Lubitz and O. Rüdiger, ChemPlusChem, 2016, 82, 540-545.

124 Y. Li and T. B. Rauchfuss, Chem. Rev., 2016, 116, 7043-7077.

125 C. Tard and C. J. Pickett, Chem. Rev., 2009, 109, 2245-2274.

126 G. A. N. Felton, C. A. Mebi, B. J. Petro, A. K. Vannucci, D. H. Evans, R. S. Glass and D. L. Lichtenberger, J. Organomet. Chem., 2009, 694, 2681-2699.

127 F. Wang, W.-G. Wang, H.-Y. Wang, G. Si, C.-H. Tung and L.-Z. Wu, ACS Catal., 2012, 2, 407-416.

128 T. S. Teets and D. G. Nocera, Chem. Commun. , 2011, 47, 9268-9274.

129 W. Wang, T. B. Rauchfuss, L. Bertini and G. Zampella, J. Am. Chem. Soc., 2012, 134, 4525-4528.

130 L. Bertini, P. Fantucci, L. De Gioia and G. Zampella, Inorg. Chem., 2013, 52, 9826-9841.

131 P. W. J. M. Frederix, Pim W J, K. Adamczyk, J. A. Wright, T. Tuttle, R. V. Ulijn, C. J. Pickett and N. T. Hunt, 
Organometallics, 2014, 33, 5888-5896.

132 S. Niu, A. E. Nelson, P. De La Torre, H. Li, C. F. Works and M. B. Hall, Inorganic Chemistry, 2019, 58, 13737-13741.

133 A. R. Ridley, A. I. Stewart, K. Adamczyk, H. N. Ghosh, B. Kerkeni, Z. X. Guo, E. T. J. Nibbering, C. J. Pickett and N. T. Hunt, Inorg. Chem., 2008, 47, 7453-7455.

134 J. Brown-McDonald, S. Berg, M. Peralto and C. Works, Inorganica Chimica Acta, 2009, 362, 318-324.

135 L. Bertini, C. Greco, L. De Gioia and P. Fantucci, The Journal of Physical Chemistry A, 2009, 113, 5657-5670.

136 A. I. Stewart, J. A. Wright, G. M. Greetham, S. Kaziannis, S. Santabarbara, M. Towrie, A. W. Parker, C. J. Pickett and N. T. Hunt, Inorganic Chemistry, 2010, 49, 9563-9573.

137 S. Kaziannis, S. Santabarbara, J. A. Wright, G. M. Greetham, M. Towrie, A. W. Parker, C. J. Pickett and N. T. Hunt, The Journal of Physical Chemistry B, 2010, 114, 15370-15379.

138 J. Marhenke, A. E. Pierri, M. Lomotan, P. L. Damon, P. C. Ford and C. Works, Inorg. Chem., 2011, 50, $11850-11852$.

139 C. J. Stromberg, C. L. Kohnhorst, G. A. Van Meter, E. A. Rakowski, B. C. Caplins, T. A. Gutowski, J. L. Mehalko and E. J. Heilweil, Vibrational Spectroscopy, 2011, 56, 219-227.

140 J. L. Bingaman, C. L. Kohnhorst, G. A. Van Meter, B. A. McElroy, E. A. Rakowski, B. W. Caplins, T. A. Gutowski, C. J. Stromberg, C. E. Webster and E. J. Heilweil, J. Phys. Chem. A, 2012, 116, 7261-7271.

141 S. Muhammad, S. Moncho, E. N. Brothers, M. Y. Darensbourg, D. J. Darensbourg and A. A. Bengali, Inorg. Chem., 2012, 51, 7362-7369.

142 R. Kania, P. W. J. M. Frederix, J. A. Wright, R. V. Ulijn, C. J. Pickett and N. T. Hunt, J. Chem. Phys., 2012, 136, 044521.

143 M. Johnson, J. Thuman, R. G. Letterman, C. J. Stromberg, C. E. Webster and E. J. Heilweil, The Journal of Physical Chemistry B, 2013, 117, 15792-15803.

144 L. Bertini, C. Greco, P. Fantucci and L. De Gioia, International Journal of Quantum Chemistry, 2014, 114, 851-861.

145 B. W. Caplins, J. P. Lomont, S. C. Nguyen and C. B. Harris, The Journal of Physical Chemistry A, 2014, 118, $11529-11540$.

146 W. A. Thornley and T. E. Bitterwolf, Chemistry - A European Journal, 2015, 21, 18218-18229.

147 R. Goy, L. Bertini, T. Rudolph, S. Lin, M. Schulz, G. Zampella, B. Dietzek, F. H. Schacher, L. De Gioia, K. Sakai and W. Weigand, Chemistry - A European Journal, 2017, 23, 334-345.

148 A. Hunt, J. Barrett, M. McCurry and C. Works, Polyhedron, 2016, 114, 306-312.

149 L. Bertini, M. E. Alberto, F. Arrigoni, J. Vertemara, P. Fantucci, M. Bruschi, G. Zampella and L. De Gioia, International Journal of Quantum Chemistry, 2018, 118, e25537.

150 R. L. Meyer, A. D. Zhandosova, T. M. Biser, E. J. Heilweil and C. J. Stromberg, Chemical Physics, 2018, 512, $135-145$.

151 C. J. Stromberg and E. J. Heilweil, The Journal of Physical Chemistry A, 2018, 122, 4023-4030.

152 W. Thornley, S. A. Wirick, M. Riedel-Topper, N. J. DeYonker, T. E. Bitterwolf, C. J. Stromberg and E. J. Heilweil, The Journal of Physical Chemistry B, 2019, 123, 7137-7148.

153 F. Arrigoni, G. Zampella, L. De Gioia, C. Greco and L. Bertini, Inorganics, 2021, 9, 16.

154 A. Meyers, E. J. Heilweil and C. J. Stromberg, J. Phys. Chem. A, 2021, 125, 1413-1423.

155 S. Roy, M. Bacchi, G. Berggren and V. Artero, ChemSusChem, 2015, 8, 3632-3638.

156 J. Ekström, M. Abrahamsson, C. Olson, J. Bergquist, F. B. Kaynak, L. Eriksson, L. Sun, H.-C. Becker, B. Åkermark, L. Hammarström and S. Ott, Dalton Trans., 2006, 4599-4606.

157 V. Artero, G. Berggren, M. Atta, G. Caserta, S. Roy, L. Pecqueur and M. Fontecave, Acc. Chem. Res., 2015, 48, 2380-2387.

158 A. K. Justice, T. B. Rauchfuss and S. R. Wilson, Angew. Chem. Int. Ed Engl., 2007, 46, 6152-6154. 